\title{
Responsibility for climate justice: the role of great powers
}

\author{
Kopra, Sanna
}

Edward Edgar

2019-11

Kopra , S 2019 , Responsibility for climate justice: the role of great powers . in P G Harris (ed.) , A Research Agenda for Climate Justice . Edward Edgar , pp. 158-170 .

http://hdl.handle.net/10138/314725

acceptedVersion

Downloaded from Helda, University of Helsinki institutional repository.

This is an electronic reprint of the original article.

This reprint may differ from the original in pagination and typographic detail.

Please cite the original version. 


\title{
Responsibility for climate justice: the role of great powers
}

\author{
Sanna Kopra
}

In: Paul G. Harris (ed.) (2019) A Research Agenda for Climate Justice. Cheltenham: Edward Elgar Publishing, pp. 158-170.

This chapter contributes to the scholarly field of climate justice by scrutinizing the role of great powers in debating and implementing climate responsibility. The contemporary literature on international environmental governance often emphasizes the role of small states, intergovernmental organizations and non-state actors in promoting ambitious climate change mitigation agendas at the local, regional or global level, often viewing great powers mostly as veto actors blocking attempts at progress in international climate negotiations (cf. Bukovansky et al. 2012, Clark 2011, Kopra 2019a). While this may often be the case in the political realm, it does not mean that we cannot - or should not - expect great powers to shoulder special responsibilities for climate change mitigation and adaptation. As Hedley Bull (2002 [1977]: 200-201) notes, the concept of great power responsibility is not a 'description of what great powers actually do' but 'rather a statement of the roles they can, and sometimes do, play that sustain international order' and justice. Therefore, this chapter asks: Can we assume that great powers shoulder more responsibility regarding climate change mitigation than smaller states?

The chapter builds on the English School of International Relations (IR) scholarship, which is a theoretical enquiry rooted in world history, international law and political theory. The English School was developed from the British Committee on the Theory of International Relations, founded in 1959, and especially the works of Hedley Bull, Herbert Butterfield, R.J. Vincent, Adam Watson and Martin Wight. Since Barry Buzan's prominent volume From International to World Society? English School Theory and the Social Structure of Globalisation was published in 2004, there has been a notable rise in English School scholarship looking at the social structures of international society. According to Hedley Bull's classic definition, this society 'exists when a group of states, conscious of certain common interests and common values, form a society in the sense that they conceive themselves to be bound by a common set of rules in their relations with one another, and 
share in the working of common institutions' (Bull, 2002 [1977]: 13). In recent years, much less attention has been paid to the normative theorization that was advanced within the English School by Andrew Linklater, Tim Dunne and Nicholas Wheeler, among others, especially in the 1990s.

In addition to its recent focus on societal approaches, the English School is also a normative and practice-guiding theory in a moral sense. As the severe impact of climate change starts to shape the practices of international society, it is high time to renew the English School's interest in moral-philosophical discussions. In order to spur discussion on how international practices ought to be in the era of climate change, this chapter studies great powers' role in international climate politics empirically and normatively. It develops a normative framework reasoning why great powers ought to shoulder special climate responsibilities and also analyses how the UN Security Council (the key great power club), as well as the United States and China (the two most powerful states in the world), define great power climate responsibilities in practice.

\section{Great powers in international society}

It is a commonplace in IR to argue that great powers not only have special rights in international society but also have special responsibilities in maintaining international order and providing public goods. While materialist theories of IR have mainly focused on the ways that shifts in the balance of power shape international order, social theories are more concerned with how power shifts influence normative settings of international relations. For the English School theory, material capabilities are essential elements of being a great power, but, more important, power is a 'social attribute' which must be placed 'side by side with other quintessentially social concepts such as prestige, authority, and legitimacy' (Hurrell 2007: 39). Thus, the concept of great power responsibility is also inherently social in nature.

In general, the English School assumes that 'even if a state reaches a certain level of material capacity and has a certain national identity, it does not automatically become a great power, but instead needs to be recognised and accepted by other recognised great powers' (Kopra 2019b: 153). Great powers need to have certain material capabilities, but foremost is an identity created in the interaction among states. What makes the English School's conception unique is that it maintains that: 
[G]reat powers are powers recognized by others to have, and conceived by their own leaders and peoples to have, certain special rights and duties. Great powers, for example, assert the right, and are accorded the right, to play a part in determining issues that affect the peace and security of the international system as a whole. They accept the duty, and are thought by others to have the duty, of modifying their policies in the light of the managerial responsibilities they bear (Bull 2002 [1977]: 196)

Due to the anarchic nature of international society, however, great powers' rights and responsibilities are not fully formalized and written into international treaties (Bull 2002 [1977]: 221), apart from Article 24 of the UN Charter (1945), which appointed permanent members of the UN Security Council to have 'primary responsibility for the maintenance of international peace and security'. Due to its members' status of legalized hegemony (Simpson 2004: 68), the UN Security Council can be viewed as the key 'great power club' (Bull 2002 [1977]: 194, Wight 1999 [1946]: 42, Kopra 2019a: 70-73) of our times. Hence, it is the members of the UN Security Council that negotiate the 'content' of great power responsibility in time and place. It indeed seems that the notion of great power responsibility is flexible concerning its content and direction: great powers mould it through their discourses and actions at UN negotiations and beyond (Kopra 2019b).

For the English School, the so-called pluralist-solidarist debate on the possibility and potential of shared interests, norms, values, rules and institutions in international society (e.g. Bain 2014, 2018) plays a key role in scholarship on the justifications and scope of great power responsibility. While pluralists emphasize the importance of great power management for sustaining international order and security of states, solidarists highlight great powers' responsibility to promote international justice, human security and the well-being of individuals globally.

Taking a very state-centric approach to international relations, pluralism is mainly concerned with interstate order in international society. From their viewpoint, international order constitutes the key means to facilitate peaceful coexistence and other ultimate goals of international society. Therefore, great powers have special managerial responsibility to maintain international order so as to "ensure that the conditions of international peace and security are upheld' (Jackson 2000: 203). Traditionally, pluralist theoretical and empirical 
enquiries have focused on great powers' responsibilities in managing their relations with one another in a prudent way in specific situations (Bull 2002 [1977]: 200, Watson 1982: 201), as well as their role in mediation of international conflicts and preservation of the general balance of international society (Watson 1982: 201). Today, however, it is increasingly clear that climate change is a potential source of international conflict, and it poses national security risks around the world (e.g. Barnett 2003). For some states, climate change is even a question of state survival. Small island states in the Asia-Pacific will be lost to rising sea levels caused by climate change in the future. Hence, it is reasonable to argue that climate change is likely to cause a risk to the status quo in the international order. From a pluralist perspective, this means that given their managerial responsibility to maintain international peace and security, great powers can be assumed to have a special responsibility to lead international efforts to reduce emissions (cf. Kopra 2019a: 74).

Solidarism is based on cosmopolitan ethics that gives moral priority to the universal rights of individuals over state sovereignty. Thus, it takes individual human beings around the world as moral referent objectives of state responsibility, including great power responsibility (see, for example, Harris 2016). Hence, solidarists underline social attributes of power and responsibility: ideational power is important. As Wheeler (2000: 2) puts it, it is important to 'distinguish between power that is based on relations of domination and force, and power that is legitimate because it is predicated on shared norms' [italics used in original].

Solidarist scholarship has focused especially on the question of humanitarian intervention and the 'responsibility to protect' (R2P) (e.g. Wheeler 2000). When it comes to great power responsibilities, solidarists underline that great powers have special responsibility to promote international justice. They promote 'universal' liberal ideas that great powers ought to advance in international relations, such as human rights, the rule of law and good governance, as 'new standards of civilization' (Gong 1984). Climate change can be added to the list due to its adverse effects on human security and well-being around the world. From a solidarist point of view, this means that due to their leadership responsibility to promote human values and international justice, great powers ought to make serious diplomatic efforts to spur the political will necessary to increase the ambition of climate change mitigation at the global level (cf. Kopra 2019a: 74).

Thus, despite its very limited interest in questions of climate change so far (see Falkner 2012, Falkner and Buzan 2017, Kopra 2019a, 2019b, Palmujoki 2013), the English School theory 
indicates that great powers can be expected to have special responsibilities in the context of climate change mitigation. The next section investigates the extent to which China, the United States and the UN Security Council acknowledge this responsibility in practice.

\section{Great powers and notions of special climate responsibility}

The UN Security Council organized the 'first-ever debate' on the nexus between climate change, energy and security in 2007 - despite China and Russia having challenged the adequacy of the Council for such a debate (United Nations 2007). The president of the Council, the British Foreign Secretary Margaret Beckett, argued, however, that the Council must address the security impact of climate change because the 'Council's responsibility [is] the maintenance of international peace and security, and climate change exacerbated many threats, including conflict and access to energy and food' (United Nations 2007). In line with this, the UN General Assembly (2009a) urged relevant UN organizations to strengthen their efforts to tackle climate change, including its 'possible security implications', and asked the UN Secretary-General to prepare a comprehensive report on the potential security impacts of climate change. In response, the Secretary-General delivered a report which defined climate change as a threat multiplier that could affect security through five channels: vulnerability, development, coping and security, statelessness, and international conflict (UN General Assembly 2009b). Two years later, the UN Security Council (2011) adopted its first-ever statement on the potential security impact of climate change. Yet it made no decision on the use of new environmental peacekeeping forces ('green helmets') in settling conflicts caused by resource scarcity (United Nations 2011). In 2013, 2018 and 2019, the Security Council also discussed climate change but failed to define it as an international security threat, especially because of the resistance from Russia and China (Krause-Jackson 2013, UN Security Council 2018, Pohl and Schalle 2019).

Nevertheless, US President Barack Obama made an explicit link between great power responsibility and climate change in his speech at the UN Climate Change Summit in 2014. After meeting there with Chinese Vice Premier Zhang Gaoli, he said that it was his belief that, 'as the two largest economies and emitters in the world, we have a special responsibility to lead. That's what big nations have to do' (Obama 2014). 
A decade prior to Obama's acknowledgement, it had become clear that China was rising to the status of a great power. Concerned about the ramifications for established liberal norms and institutions, the United States called China to become a 'responsible stakeholder' (Zoellick 2005) and to take 'a role in which a growing economy is joined by growing responsibilities' in international society (White House 2009). As China had surpassed the United States as the biggest carbon dioxide emitter in the world in 2006 (PBL Netherlands Environmental Assessment Agency 2007), climate responsibility was incorporated into the broader calls for China's enhanced great power responsibility. Since the Chinese government did not want to be regarded as an international threat, it developed the concept of 'peaceful development' and started a campaign to pursue a favourable international image (e.g. Deng 2008). On the one hand, the scope of international responsibility remained heavily debated in China (Shambaugh 2013); on the other hand, the state's badly damaged international image in the 2009 Copenhagen climate conference increased the pressure on China to take a more constructive role in international climate negotiations (Kopra 2012). In addition, domestic environmental problems were an important driver for China's growing willingness to address climate change. Over the years, the Chinese government seemed to learn that climate responsibility was a beneficial way to describe China's great power responsibility. In contrast to other attributes of great power responsibility, such as R2P, climate responsibility is not based on the Western liberal ideals. Besides, the fulfilment of climate responsibility was not viewed by the Chinese as hampering the state's overall national interests. Rather, 'greenification' of its economy would support its ongoing structural reforms (Kopra 2019a).

In 2014, China's Special Envoy Zhang Gaoli announced at the UN Climate Summit that 'responding to climate change is what China needs to do to achieve sustainable development at home as well as to fulfil its due international obligation as a responsible major country' (Zhang 2014). President Xi Jinping (2014) also declared at the 2014 APEC that as 'its overall national strength grows, China will be both capable and willing to provide more public goods for the Asia-Pacific and the world'. Although Xi did not explain what he was referring to by 'public goods', his comment hinted that China could be willing to shoulder great climate responsibility as well: clean air is a 'public good'. Notably, a few days later, Presidents Xi and Obama indeed informed the world in their historic joint climate statement that China would stop the growth of its carbon dioxide emissions by around 2030 (White House 2014). The joint statement encouraged international society to believe that an international climate treaty was possible to reach in Paris in the following year, not least due to the acceptance of 
the United States and China to take great power responsibility to lead international efforts to tackle climate change. The Paris Agreement on climate change was adopted in 2015, and China and the United States were among the first countries to ratify the Paris Agreement in September 2016 - a decision that was made public in a joint press conference indicating once again great power climate responsibility, which probably increased the willingness of other states to ratify it as well. The Paris Agreement entered into force on 4 November 2016, and only a few days later climate sceptic Donald J. Trump was elected president of the United States - an election that ended great power cooperation on climate change at once.

Due to Trump's reluctant approach to international climate politics, and particularly his decision to withdraw the United States from the Paris Agreement, many policy-watchers around the globe now expect China to fulfil the leadership vacuum left by the United States. For China, climate responsibility indeed seems to be an appealing way of defining great power responsibility in the 21st century (Kopra 2019a, 2019b). In practice, however, China has used its increased bargaining power to reintroduce the bifurcation between developed and developing countries in the allocation of international responsibilities - a division abandoned by the Paris Agreement. Presently, China's nationally determined contribution to the Paris Agreement is 'little more than business as usual' (Harris 2017: 102) and 'highly insufficient' (Climate Action Tracker 2018) to prevent dangerous climate change from happening. In short, China has not pledged to reduce its absolute emissions but only its relative emissions per unit of gross domestic product. Moreover, it has promised to achieve the peak in emissions growth around 2030 without mentioning how much its emissions will increase before the peak. On the one hand, it is fair that China emphasizes its 'development first' principle, given that a big proportion of its population continues to live in poverty. On the other hand, China's climate policies fail to acknowledge that the country's new, rapidly growing, members of its affluent class produce as much as - or even more - greenhouse gas emissions than many Europeans and Americans, but those Chinese people are able to 'hide behind China's developing country status' (Harris 2017: 105).

As Harris $(2010,2017)$ proposes, a principle of common but differentiated responsibilities among people (instead of that among countries, as in the international climate change agreements) would better capture the global role of affluent Chinese individuals and therefore promote genuine solidarist climate responsibility in international society. Clearly, this is not how China or other great powers define climate responsibility. In addition to the lack of 
ambition in its domestic climate policies, China has not initiated innovative or effective solutions to increase ambition for emissions reduction at the global level. Hence, it remains very unclear whether China really will be - or even wants to be - an inspirational leader that can truly lead in international climate politics.

\section{Pluralist-solidarist debate and the fulfilment of great power climate responsibility}

The present 'great power club' has not put forward notions of great power climate responsibility in a way that is ambitious enough to prevent dangerous climate change from happening. This opens up a critical normative question: How should great powers define their special climate responsibility, and more important, how should they operationalize that responsibility in practice? The English School's pluralist-solidarist debate can help us to address great power responsibilities in the era of climate change. A new English School research agenda looking at great power climate responsibility is needed.

Although the English School in general has its roots in the social theories of IR, its pluralist camp comes quite close to the basic tenets of Realism, especially the tendency to emphasize the material dimensions of power. Since pluralism focuses on the 'is-side' (as opposed to the 'ought-side') of international relations, it is natural that its conception of great power responsibility stresses the importance of the material capabilities of great powers to maintain international order. Military capability is often regarded as a - if not the - key attribute of great powers: they are allowed to use armed force, and indeed they are required to do so, if it is needed to maintain international order. Traditionally, coercion has not been viewed as a feasible means of climate change mitigation. However, the role of military power cannot be fully ignored when discussing great power climate responsibility. If climate change proceeds in a disastrous and abrupt manner, it is not very hard to imagine militarization of climate change. Since the UN Security Council has already addressed climate change, it is possible that new climate peacekeeping forces will be established in the future. In line with the Council's mandate, great powers would then play a key role in making decisions as to how and where those forces would be used.

From a pluralist perspective, great powers can fulfil their managerial responsibilities in international society by pursuing their interests with prudence. They should not jeopardize international order but act in accordance with laws and practices sustaining it. Upholding 
international law is thus an important attribute of great power responsibility: great powers must obey international law in order to maintain international order and legalize their hegemonic status (Simpson 2004). When President Trump decided to withdraw the United States from the Paris Agreement in accordance with the rules of the agreement itself, he did not violate international law per se. Yet Trump's decision was widely criticized around the world, which demonstrates that responsible international actors are expected to participate in the workings of international regimes and organizations (Kopra 2019b: 151-2). Moreover, one reason for the criticism may have been that Trump's hostility towards climate politics is not 'in conformity with a rule, even though that rule is not agreed, not enunciated nor even fully understood' (Bull 2002 [1977]: 216), of great power climate responsibility. The pluralist approach condemns the United States for not fulfilling its great power responsibility because the withdrawal from the Paris Agreement undermines climate change mitigation and thus increases international climate-related security risks that may shake up international order.

Moreover, pluralist ethics also maintains that in line with their material capabilities, great powers bear a special responsibility to solve the problem of climate change. Since efficient emissions reductions are regarded as a key means of stopping climate change, great powers can be expected to implement the biggest share in emissions reduction. In other words, great powers must prepare and implement effective domestic climate change mitigation plans. It is worth noting that the ratification of an international climate agreement is not a precondition to fulfilment of this domestic responsibility, but a state may nevertheless prove to be a responsible member of international society by undertaking ambitious domestic measures to mitigate climate change on a voluntary basis. In that case, climate change mitigation plans presumably support its overall national interests, which is a sufficient justification from the perspective of pluralism.

For the solidarist wing of the English School, however, national interests are not a legitimate reason on which great power responsibility should rest; great power responsibility has to be based on human values and international justice. As other chapters in this volume make very clear, climate change is inherently an issue of human security and international justice. It is a matter of equity and social and distributive justice, and it violates basic human rights, such as the right to life, the right to health and the right to subsistence (see Harris 2016). Given great powers' special responsibility to decrease human suffering, solidarist ethics assumes them to shoulder special responsibility in tackling climate change. Due to the impending human 
security effects of climate change, it is possible that the scope of R2P will expand in the future. A norm of 'responsibility to protect climate' may emerge, and great powers can be expected to play a central role in that process as well as in implementing that norm in practice. From a solidarist perspective, however, the UN Security Council may not be a legitimate forum to address that norm because, without a reform, the Council is unable to truly promote international justice. In the present form, its membership is based on the postWorld War II international order and its military and sanction-based tools are not designed to solve non-traditional security issues or to promote human well-being, for instance. Hence, a new, more representative international forum would be necessary to advance a genuinely solidarist 'green' R2P from climate change.

For many English School scholars, international law is one of the most important institutions of international society. It is constitutive of international society as it captures shared rules of coexistence accepted by members of international society at large. Yet compliance with international law can hardly be seen as an ambitious attribute of great power responsibility because it tends to pronounce only a minimum standard of conduct in international society. Truly responsible members of that society can be expected to do more. Generally, both pluralists and solidarists agree that it is sometimes necessary to violate international law in order to advance the common good of international society. According to pluralist ethics, great powers have a responsibility to act against international law if it is necessary for the maintenance of international order (Bull 2002 [1977]: 138). Moreover, solidarists notice that, like all human constructions, international law may be imperfect and unfair; it may undermine fundamental human values, for instance. In that case, great powers should undertake ambitious diplomatic efforts to develop new, more just international norms and rules.

As for climate law, international climate treaties are not consistent with scientific models of required actions to halt climate change. For instance, states' nationally determined contributions to the Paris Agreement are highly insufficient to reach the goal of limiting the global temperature rise to 2 degrees Celsius (UN Environment 2018), not to mention the goal of 1.5 degrees Celsius that the recent report of the Intergovernmental Panel on Climate Change (2018) regards as the precondition for a safer future. Therefore, solidarists assume responsible great powers should go well beyond the basic requirements of international (climate) law by promoting human values and well-being globally. They should do this on a 
voluntary basis as well as by taking a leadership role in international negotiations on more ambitious climate mitigation and adaptation policies.

Furthermore, solidarist ethics opens up an intriguing question about the relationship between great power responsibility and sacrifice: Do we expect that responsible great powers should sacrifice their own good for the good of international society? In the context of international climate politics, do we assume that a responsible global leader puts its own national interests aside and commits itself to (economic) sacrifices to make a low-carbon international society possible? Evidently, neither the United States nor China has viewed their great power climate responsibilities in this way. Trump's decision to withdraw the United States from the Paris Agreement clearly dismissed the common good of human beings globally. He focused exclusively on the very narrowly defined national interests of the United States. China's climate policies are not formulated for the sake of climate mitigation per se, but they combine responses to other domestic challenges unrelated to the common good of international society, such as national energy security, domestic legitimacy, a health crisis due to air pollution, and the necessity to reform the 'old' economic growth model (Harris 2013, Kopra 2019a). Hence, the two great powers' notions of (great power) climate responsibility are very pluralist in nature, and pluralist viewpoints of responsibility are not committed to promoting international justice. To enhance international climate justice, it is thus necessary to develop the English School's solidarist notions of great power responsibility as soon as possible.

\section{Conclusion}

Climate change will cause serious harm to human security and increase social disparities around the world in the coming decades. It will also likely induce a profound transformation in the workings of international society, including practices of great power management. However, surprisingly few English School scholars have addressed climate change - and when they have, they have largely focused on the empirical and sociological aspects of international climate politics. In the era of climate change, however, the English School should go beyond structural analyses and restore moral-philosophical debate to the heart of its scholarship. With this chapter I have sought to spur normative theorization within the English School by analysing great powers' special responsibility for climate change mitigation. I identified two ethical lines of reasoning for great power climate responsibility. First, a pluralist approach underlines the great powers' managerial responsibility to maintain 
interstate order. Because climate change undermines that order, great powers have a special responsibility to implement a substantial share of the reduction of global emissions. Second, a solidarist approach highlights great powers' leadership responsibility to promote international justice and human values around the world. Since climate change undermines equity and the well-being of individuals, great powers should undertake efficient climate mitigation actions at home and assume a leadership role in international negotiations to enhance ambition for emissions reductions at the global level.

During Barack Obama's presidency, the United States and China seemed to reach an agreement that - to paraphrase Spiderman - with great climate power comes great climate responsibility. Although the UN Security Council has not issued a formal resolution on climate change, the fact that it has discussed climate security several times indicates this development as well. In practice, however, the UN Security Council, the United States and China have not lived up to their special responsibility to respond to climate change. Global greenhouse gas emissions continue to grow at a very worrying pace (e.g., Le Quéré et al. 2018), putting international society on track to face the most severe impacts of climate change. From the English School viewpoint, this means there is an urgent need for a paradigm shift in international security: climate change must be identified as a key security threat in our time. Given their special responsibility for the maintenance of international peace and security, great powers must immediately accept and live up their special climate responsibility. The UN should take a clear stand on climate security, China should take robust action to halt its emissions growth as soon as possible, and the US should renew its leadership role in international climate politics, without delay.

If the next US president fails to do that, China's climate leadership becomes even more critical in the future: global emissions peak is not possible without China's contribution. There are domestic incentives for China to take a leadership role in international climate politics because such a role would support its domestic reforms, decrease local pollution, improve energy security, and cultivate China's status as a responsible great power in international society. As an autocratic state, however, China does not have very strong prospects for representing itself as an inspirational global leader that manages to facilitate much-needed political ambition to make international society truly 'green'. This, in turn, calls for the renewal of the great power climate responsibility by the United States. Without ambitious great power leadership, international efforts to tackle climate change are likely to 
remain insufficient and slow. Hence, an urgently pressing question that future research must address is this: how can we encourage great powers to acknowledge and act out their special climate responsibilities? Civil society actors should also engage in this discussion due to their norm-entrepreneur role in international climate politics.

When it comes to the international justice implications of great power climate responsibility, the English School's pluralist and solidarist approaches are likely to have very distinct practical outcomes. The pluralist notion of great power climate responsibility seems to increase the likelihood of the militarization of climate change and is not likely to promote genuine international (climate) justice. In contrast, solidarism, which is based on cosmopolitan ethics, undoubtedly has a lot of potential to promote international climate justice not only amongst states, but also amongst globally affluent individuals (cf. Harris 2010, 2016). Currently, however, solidarism remains a very underdeveloped area within the English School because of doubts concerning whether it is really possible for states to go beyond pluralism in practice. This is lamentable, as climate change can particularly be seen as a showcase for solidarist ethics.

Future research needs to seize the big picture of great power climate responsibility. In addition to the securitization of climate change, what other normative dimensions give reason to expect that great powers might shoulder special responsibilities in international climate politics? With a new research agenda on solidarist climate ethics, the English School has a great deal of potential to enhance international climate justice in general, and the role of great powers in implementing it in particular. For the future of international society, there could not be a more pressing and urgent research agenda than the implementation of great power climate responsibility.

\section{Acknowledgement}

This research was funded by the Academy of Finland (project no. 315402).

\section{References}

Bain, William (2014), 'The pluralist-solidarist debate in the English School', in Cornelia Navari and Daniel M. Green (eds), Guide to the English School in International Studies, Chichester: John Wiley and Sons, pp. 159-69. 
Bain, William (2018), 'The pluralist-solidarist debate in the English School', Oxford Research Encyclopedia of International Studies, DOI:

10.1093/acrefore/9780190846626.013.342.

Barnett, Jon (2003), 'Security and climate change', Global Environmental Change, 13(1), 717.

Bukovansky, Mlada, Ian Clark, Robyn Eckersley, Richard Price, Christian Reus-Smit and Nicholas J. Wheeler (2012), Special Responsibilities. Global Problems and American Power, New York: Cambridge University Press.

Bull, Hedley (2002 [1977]), The Anarchical Society. A Study of Order in World Politics, 3rd edn, Basingstoke: Macmillan Press.

Clark, Ian (2011), Hegemony in International Society, New York: Oxford University Press.

Climate Action Tracker (2018), China, 30 November, accessed 3 April 2019 at:

https://climateactiontracker.org/countries/china/.

Deng, Yong (2008), China's Struggle for Status. The Realignment of International Relations, Cambridge: Cambridge University Press.

Falkner, Robert (2012), 'Global environmentalism and the greening of international society', International Affairs, 88(3), 503-22.

Falkner, Robert and Buzan, Barry (2017), 'The emergence of environmental stewardship as a primary institution of global international society', European Journal of International Relations, https://doi.org/10.1177/1354066117741948.

Gong, Gerrit W. (1984), The Standard of 'Civilization' in International Society, Oxford: Clarendon Press.

Harris, Paul G. (2010), World Ethics and Climate Change. From International to Global Justice, Edinburgh: Edinburgh University Press.

Harris, Paul G. (2013), What's Wrong with Climate Politics and How to Fix it, Cambridge: Polity.

Harris, Paul G. (2016), Global Ethics and Climate Change, Edinburgh: Edinburgh University Press.

Harris, Paul G. (2017), 'China's Paris pledge on climate change: inadequate and irresponsible', Journal of Environmental Studies and Sciences, 7(1), 102-107. Hurrell, Andrew (2007), On Global Order: Power, Values, and the Constitution of International Society, Oxford: Oxford University Press.

Intergovernmental Panel on Climate Change (2018), 'Global warming of $1.5^{\circ} \mathrm{C}$. An IPCC special report on the impacts of global warming of $1.5^{\circ} \mathrm{C}$ above pre-industrial levels and 
related global greenhouse gas emission pathways, in the context of strengthening the global response to the threat of climate change, sustainable development, and efforts to eradicate poverty', Geneva: World Meteorological Organization.

Jackson, Robert H. (2000), The Global Covenant, Oxford: Oxford University Press.

Kopra, Sanna (2012), 'Is China a responsible developing country? Climate change diplomacy and national image building', Social and Cultural Research Occasional Paper, accessed 29 May 2017 at: http://digitalcommons.pace.edu/global_asia_journal/13/.

Kopra, Sanna (2019a), China and Great Power Responsibility for Climate Change, London, UK and New York, NY, USA: Routledge.

Kopra, Sanna (2019b), 'China, great power management, and climate change: negotiating great power climate responsibility in the UN', in Tonny Brems Knudsen and Cornelia Navari (eds), International Organization in the Anarchical Society. The Institutional Structure of World Order, New York: Palgrave Macmillan, pp. 149-73.Krause-Jackson, Flavia (2013), 'Climate change's links to conflict draws UN attention', Bloomberg, 15 February, accessed 24 September 2016 at: http://www.bloomberg.com/news/articles/2013-02-15/climate-changes-links-to-conflict-draws-un-attention.

Le Quéré, Corinne, Robbie M. Andrew, Pierre Friedlingstein, Stephen Sitch, Judith Hauck, Julia Pongratz, Penelope A. Pickers et al. (2018), 'Global carbon budget 2018', Earth System Science Data, 10, 2141-94.

Obama, Barack (2014), 'Remarks by the president at U.N. climate change summit', accessed 6 February 2019 at: https://obamawhitehouse.archives.gov/the-pressoffice/2014/09/23/remarks-president-un-climate-change-summit. Palmujoki, Eero (2013), 'Fragmentation and diversification of climate change governance in international society', International Relations, 27(2), 180-201.

PBL Netherlands Environmental Assessment Agency (2007), China Now No. 1 in CO2 Emissions; USA in Second Position, accessed 3 April 2019 at: https://www.pbl.nl/en/dossiers/Climatechange/Chinanowno1inCO2emissionsUSAinsecondpo sition.

Pohl, Benjamin and Stella Schalle (2019), 'Security Council debates how climate disasters threaten international peace and security', Climate Diplomacy, 30 January, accessed 3 April 2019 at: https://www.climate-diplomacy.org/news/security-council-climate-disastersthreaten-international-peace-and-stability.Shambaugh, David (2013), China Goes Global: The Partial Power, New York: Oxford University Press. 
Simpson, Gerry (2004), Great Powers and Outlaw States. Unequal Sovereigns in the International Legal Order, Cambridge: Cambridge University Press.

UN Environment (2018), Emissions Gap Report 2018, accessed 4 April 2019 at:

https://www.unenvironment.org/resources/emissions-gap-report-2018.

UN General Assembly (2009a), Climate Change and its Possible Security Implications, A/RES/63/281, 85th plenary meeting, 3 June.

UN General Assembly (2009b), Climate Change and its Possible Security Implications. Report of the Secretary-General, A/64/350, 11 September.

United Nations (2007), 'Security Council holds first-ever debate on impact of climate change on peace, security, hearing over 50 speakers', accessed 29 May 2017 at:

http://www.un.org/press/en/2007/sc9000.doc.htm.

United Nations (2011), 'Security Council, in statement, says 'contextual information' on possible security implications of climate change important when climate impacts drive conflict', accessed 29 May 2017 at: http://www.un.org/press/en/2011/sc10332.doc.htm. UN Security Council (2011), 'Statement by the President of the Security Council', S/PRST/2011/15, 20 July.

UN Security Council (2018), 'Maintenance of international peace and security. understanding and addressing climate-related security risks', S/PV.8307, 11 July.

Watson, Adam (1982), Diplomacy. The Dialogue Between States, London: Eyre Methuen. Wheeler, Nicholas J. (2000), Saving Strangers: Humanitarian Intervention in International Society, Oxford: Oxford University Press.

White House (2009), 'Joint press statement by President Obama and President Hu of China', accessed 6 February 2019 at: https://obamawhitehouse.archives.gov/the-press-office/jointpress-statement-president-obama-and-president-hu-china.

White House (2014), 'U.S.-China joint announcement on climate change', accessed 6 February 2019 at: https://www.whitehouse.gov/the-press-office/2014/11/11/us-china-jointannouncement-climate-change.Wight, Martin (1999 [1946]), Power Politics, London: Leicester University Press.

Xi, Jinping (2014), 'Seek sustained development and fulfil the Asia-Pacific dream', accessed 29 May 2017 at:

http://www.fmprc.gov.cn/mfa_eng/topics_665678/ytjhzzdrsrcldrfzshyjxghd/t1210456.shtml. Zhang, Gaoli (2014), 'Build consensus and implement actions for a cooperative and win-win global climate governance system', accessed 29 May 2017 at: http://www.fmprc.gov.cn/mfa_eng/zxxx_662805/t1194637.shtml. 
Zoellick, Robert B. (2005), 'Whither China: from membership to responsibility? Remarks to national committee on U.S.-China relations', accessed 29 May 2017 at: http://20012009.state.gov/s/d/former/zoellick/rem/53682.htm. 